\title{
Gelatinization of fermented cassava tuber meal and its nutritive value for broilers
}

\author{
Enyenihi, G. E., Esiegwu, A. C., Esonu, B. O., Uchegbu, M. C. and Udedibie*, A. B. I. \\ Federal University of Technology \\ Department of Animal Science and Technology \\ P. M. B. 1526, Owerri - Nigeria \\ *Corresponding author: email: abiu_futo@yahoo.com
}

\begin{abstract}
The effect of fermentation of cassava tuber followed by its gelatinization was evaluated as a method of processing cassava for use as source of energy in broiler diets. Peeled and unpeeled cassava tubers were separately fermented in water for 4 days, dried in the sun and then milled to produce fermented peeled and unpeeled cassava tuber meals, respectively. The dusty meals were then gelatinized by mixing with water in pots seated over fire at the rate of $1 \mathrm{~kg}$ of cassava tuber meal to one litre of water and stirred until they gelatinized into fufu. The gelatinized pastes were then taken bit by bit and flattened on polythene sheets and dried in the sun. The resultant fermented and gelatinized peeled and unpeeled cassava tuber cakes were then milled to produce fermented and gelatinized unpeeled cassava tuber meal (UFGC), a brownish-looking non-dusty product and fermented and gelatinized peeled cassava tuber meal (PFGC), an ash-looking non-dusty product. Three broiler diets were made such that diet 1 (control) contained maize as source of energy, while in diets 2 and 3, the maize in the control diet was completed replaced with UFGC and PFGC, respectively, both in the starter and finisher diets. One hundred and twenty (120) broiler chicks were divided into 3 groups of 40 birds each and each group assigned to one of the diets, using completely randomized design, and fed for 4 weeks with the starter diets and finisher diets for another 4 weeks. At the starter phase, the UFGC diets gained significantly $(P<0.05)$ less weight and consequently had poorer feed conversion ratio. There were no significant differences in feed intake $(P<0.05)$. At the finisher phase, the group on UFGC gained significantly $(P<0.05)$ more body weight. The groups on cassava diet tended to consume less feed and so had better feed conversion ratio. There were no differences $(P>0.05)$ in dressed weights and weights of internal organs but the group on PFGC diet accumulated significantly $(P<0.05)$ more abdominal fat.
\end{abstract}

Keywords: Broiler, Cassava, diet, fermentation, gelatinization.

\section{Introduction}

Cereal grains form the bulk of commercial poultry feeds, with maize having the highest inclusion rate of $40-50 \%$ as compared to other cereal grains (Udedibie, 2003). The demand for maize has, however, exceeded its supply in Nigeria because it is also used as staple food for a large proportion of Nigerians, as well as industrial raw material (Udedibie and Asoluka, 2008). This invariably has contributed to high cost of poultry feeds in the country with concomitant increase in cost of poultry products. There is the need, therefore, for the use of other readily available alternatives if poultry industry in the country has to survive.

One of the energy sources that has great potential as alternative to maize is cassava. Cassava is a plant originating from South America and is known under various names: Manihot esculenta, manioc, yucca and tapioca. The tubers (part of the root system) and the leaves are used as food sources (Ayasan, 2010). According to the author, it is an important staple in many 
developing countries of Africa, South and Central America, India and Southern Asia.

Nigeria is the largest producer of cassava in the world, with production estimate of about 33 million metric tonnes per annum (FAO, 2005). The potential of cassava as an energy feed is enormous despite its limitations. It is low in crude protein as compared to maize but this can be remedied by balancing with high protein feeds (Udedibie et al., 2008). It has short-shelf life and is high in cyanogenic glucosides, linamarin and lotaustralin, which on hydrolysis yield hydrogen cyanide $(\mathrm{HCN})$, which is highly toxic (Udedibie et al., 2004; Sayre, 2007; Chauynarong et al., 2009). It is dusty and therefore affects feed intake of young birds (Udedibie et al., 2004).

Various methods have been used in processing cassava tuber so as to render it utilizable in poultry feeds. These include cooking, sun-drying, use of additives and fermentation (Obioha et al., 1984; Manhungu et al.,1987; Odukwe, 1994; Udedibie et al., 2004). Udedibie et al. (2004) have demonstrated that fermentation before drying is a better processing method than direct sun-drying.

A report by Bradbury (2004) has shown that cyanide content of sun-dried cassava flour could be greatly reduced if it is wetted and thinly spread for 5 hours before cooking for human consumption. Enyenihi et al. (2009) demonstrated that $\mathrm{HCN}$ content of cassava flour so processed was reduced to about $1 / 5$ of the original level and the cassava flour so processed had no deleterious effects on performance of laying hens. The product was however, dusty and so rendered the diets dusty too.

Traditionally, fermentation has remained the best way to eliminate $\mathrm{HCN}$ from cassava (Udedibie et al., 2004). However, fermented cassava flour still has the limitation of dustiness and short shelf-life.
Chukwuemeka (2009) and Emeh (2009) have demonstrated that when fresh cassava tubers are boiled for an hour, they gelatinize and yield non-dusty cassava tuber meal when dried and milled. However, when used in place of maize in balanced broiler diets, it depressed growth performance of broilers. Analysis of the meal for $\mathrm{HCN}$ using picrate paper method of Bradbury et al. (1999) showed that the method still contained up to $50 \mathrm{ppm} \mathrm{HCN}$, which is still considered high in poultry diets. It may therefore follow that gelatinization of fermented cassava tuber, which is already $\mathrm{HCN}$-free could be the solution to limitations of cassava tuber as feedstuff in poultry diets.

The study herein reported was therefore designed to determine the efficacy of fermentation followed by gelatinization as a method of processing cassava tubers for use as alternative to maize in broiler diets.

\section{Materials and Methods \\ Experimental site}

The experiment was carried out in the Poultry Unit of the Teaching and Research Farm and the Animal Science Laboratory of the Federal University of Technology Owerri, Imo State - Nigeria. Owerri is in the South-eastern agro-ecological zone of Nigeria. It lies between latitude $4^{\circ} 4^{1}$ and $6^{\circ} 3^{1}$ and longitude $6^{\circ} 15^{1}$ and $8^{\circ} 15^{1}$ with mean annual rainfall, temperature and relative humidity of $2500 \mathrm{~mm}, 26.5-27^{\circ} \mathrm{C}$ and 70 $80 \%$, respectively. The duration of the dry season (number of months with less than 65 $\mathrm{mm}$ of rainfall) is 3 months and the annual evapo-transpiration is $1450 \mathrm{~mm}$. the soil is sandy loam with average $\mathrm{pH}$ of 5.5 (Adeyemi, 2011).

Source and processing of the cassava tubers

Fresh cassava tubers of bitter variety were 
procured from a local market and divided into 2 batches. One batch was peeled while the other was left unpeeled. Samples of both batches were analyzed for HCN content, using the picrate paper method of Bradbury etal. (1999).

The peeled and unpeeled tubers were washed, cut into pieces of about similar sizes and separately fermented for 4 days in plastic vats under atmospheric temperature. The fermented tubers were then put in sacs, pressed to reduce water content and then spread in the sun to dry. Thereafter, they were milled using a hammer mill with $2 \mathrm{~mm}$ sieve to produce fermented peeled and unpeeled cassava tuber meals, respectively. The two dusty cassava products were then subjected to gelatinization process. This involved mixing the meal in water in a pot seated on fire at the rate of $1 \mathrm{~kg}$ of the meal to 1 litre of water and the mixture stirred until it sufficiently gelatinized into $f u f u$, the cooked form in which cassava is consumed by humans.

The products were then taken bit by bit and flattened on polyethylene sheets and left to dry into cakes under the sun. The cakes were considered adequately dried when they became crispy to the touch and snapped at binding. They were then milled in a hammer mill with $2 \mathrm{~mm}$ sieve to produce peeled fermented and gelatinized cassava tuber meal (PFGC) and unpeeled fermented and gelatinized cassava tuber meal (UFGC), respectively. Their samples were subjected to both proximate and $\mathrm{HCN}$ analysis, according to AOAC (1995) and Bradbury et al. (1999), respectively.

\section{Experimental diets}

Three broiler starter diets $(\sim 23 \% \mathrm{CP}$; $\sim 2.75 \mathrm{Mcal} / \mathrm{kg} \mathrm{ME}$ ) were made such that diet 1 (control) contained maize as the main source of energy. In diets 2 and 3, the maize in diet 1 was completely replaced with PFGC and UFGC, respectively. Other ingredients were adjusted in such a way as to make the diets similar in crude protein and energy. Similarly, 3 broiler finisher diets were prepared for the finisher phase of the trial. The ingredient and chemical compositions of the diets are presented in Table 1.

\section{Experimental birds and design}

A total of 120 day-old broiler chicks of Anak strain weighing on the average $39.5 \pm$ $2.4 \mathrm{~g}$ were bought from a reputable distributor. They were collectively given a commercial broiler starter mash for one week and then divided into 3 groups of 40 birds each and each group randomly assigned to one of the three experimental diets, using completely randomized design. Each group was further subdivided into replicates of 10 birds each and each replicate housed in a $1.5 \times 2 \mathrm{~m}$ pen, with wood shavings as litter material. Electricity and kerosene lanterns were used to provide heat for the birds for 3 weeks. Feed and water were provided ad libitum. All necessary prophylactic medications and vaccinations were also provided.

The birds were weighed at the beginning of the trial and weekly thereafter. The starter phase lasted for 4 weeks. At the end of the phase, the diets were changed with the finisher diets and the trial continued for another 4 weeks.

\section{Data collection and analysis}

The birds were weighed at the beginning of each phase, to obtain their initial body weights and then weekly, thereafter. Daily feed intake was determined by subtracting the weight of left-over feed from the weight of the feed fed the previous day. Data collected included initial body weight, weekly body weight, final body weight, daily feed intake, feed conversion ratio ( $g$ feed/g gain).

A the end of the feeding trial, four birds were randomly selected from each 
treatment (one per replicate) and used for evaluation of carcass and internal organ weights, as well as the weights of the abdominal fat. They were starved of feed overnight and then sacrificed by severing their necks with sharp knife after they had been weighed. Thereafter, they were defeathered, eviscerated and the internal organs, as well as the abdominal fat removed and weighed.

Data generated were subjected to analysis of variance (ANOVA) using SPSS (2004). Where ANOVA detected treatment effects, means were compared using Duncan's New
Multiple Range Test (Snedecor and Cochran, 1978).

\section{Results and Discussion \\ Physio-chemical nature of the processed cassava tubers}

The fermented peeled and gelatinized cassava tuber meal (PFGC) looked like milled polished rice, devoid of dustiness and could store as long as the owner may want to keep it as earlier reported by Udedibie et al. (2008). The fermented unpeeled and gelatinized cassava tuber

Table 1: Ingredient and nutrient composition of the experimental starter and finisher broiler diets

\begin{tabular}{|c|c|c|c|c|c|c|}
\hline \multirow[b]{2}{*}{ Ingredients (\%) } & \multicolumn{3}{|c|}{ Starter } & \multicolumn{3}{|c|}{ Finisher } \\
\hline & Control & $\begin{array}{r}\text { PFGC } \\
\text { diet* }\end{array}$ & $\begin{array}{l}\text { UFGC } \\
\text { diet }^{* *}\end{array}$ & Control & $\begin{array}{r}\text { PFGC } \\
\text { diet* }\end{array}$ & $\begin{array}{l}\text { UFGC } \\
\text { diet** }^{2}\end{array}$ \\
\hline Yellow maize & 50.00 & 0.00 & 0.00 & 60.00 & 0.00 & 0.00 \\
\hline Cassava tuber meal & 0.00 & 50.00 & 50.00 & 0.00 & 55.00 & 55.00 \\
\hline Soybean meal (48\% CP) & 28.00 & 30.00 & 30.00 & 18.00 & 22.00 & 22.00 \\
\hline Fishmeal (65\% CP) & 2.00 & 2.50 & 2.50 & 2.00 & 3.00 & 3.00 \\
\hline Bloodmeal (80\% CP) & 3.00 & 3.50 & 3.50 & 2.00 & 4.00 & 4.00 \\
\hline Palm kernel cake & 4.00 & 4.00 & 4.00 & 4.00 & 4.00 & 4.00 \\
\hline Wheat offal $(22 \% \mathrm{CP})$ & 9.00 & 6.00 & 6.00 & 10.00 & 8.00 & 8.00 \\
\hline Bone meal & 3.00 & 3.00 & 3.00 & 3.00 & 3.00 & 3.00 \\
\hline Common salt & 0.25 & 0.25 & 0.25 & 0.25 & 0.25 & 0.25 \\
\hline TM/Vit. Premix $* * *$ & 0.25 & 0.25 & 0.25 & 0.25 & 0.25 & 0.25 \\
\hline L-Lysine & 0.25 & 0.25 & 0.25 & 0.25 & 0.25 & 0.25 \\
\hline L-Methionine & 0.25 & 0.25 & 0.25 & 0.25 & 0.25 & 0.25 \\
\hline Total & 100 & 100 & 100 & 100 & 100 & 100 \\
\hline \multicolumn{7}{|c|}{ Calculated chemical composition (\% DM) } \\
\hline Crude protein & 22.54 & 22.62 & 22.62 & 18.95 & 18.87 & 18.92 \\
\hline Ether extract & 4.37 & 7.05 & 7.05 & 3.48 & 6.53 & 6.53 \\
\hline Crude fibre & 3.78 & 2.86 & 3.46 & 3.95 & 2.92 & 3.46 \\
\hline Ash & 3.40 & 4.67 & 4.67 & 3.04 & 4.30 & 4.36 \\
\hline NFE & 65.91 & 63.50 & 62.20 & 70.55 & 68.13 & 66.73 \\
\hline Calcium & 1.31 & 1.40 & 1.40 & 1.86 & 1.78 & 1.78 \\
\hline Phosphorus & 1.03 & 0.82 & 0.82 & 1.10 & 1.18 & 1.18 \\
\hline $\mathrm{ME}(\mathrm{Mcal} / \mathrm{kg})$ & 2.70 & 2.84 & 2.74 & 2.94 & 2.98 & 2.98 \\
\hline
\end{tabular}

$*$ PFGC $=$ peeled, fermented and gelatinized cassava tuber meal.

$* *$ UFGC $=$ unpeeled, fermented and gelatinized cassava tuber meal.

*** Provided the following per $\mathrm{kg}$ of feed: vitamin $\mathrm{A}, 12,000 \mathrm{iu}$; vitamin $\mathrm{D}_{3}, 2,500 \mathrm{iu}$; vitamin $\mathrm{E}$, 8mg; vitamin $\mathrm{K}_{3}, 2 \mathrm{mg}$; vitamin $\mathrm{B}_{1}, 23 \mathrm{mg}$; vitamin $\mathrm{B}_{2}, 5 \mathrm{mg}$; vitamin $\mathrm{B}_{6}, 4 \mathrm{mg}$; vitamin $\mathrm{B}_{12} 8 \mathrm{mg}$, Niacin, $15 \mathrm{mg}$; pantothenic acid, $6 \mathrm{mg}$; folic acid, $4 \mathrm{mg}$; Manganese, $8 \mathrm{mg}$; zinc, $0.05 \mathrm{mg}$; iron, 20 $\mathrm{mg}$; copper, $3 \mathrm{mg}$; iodine, $1.2 \mathrm{mg}$; selenium, $0.16 \mathrm{mg}$; cobalt, $2 \mathrm{mg}$. 
Enyenihi, Esiegwu, Esonu, Uchegbu, and Udedibie

Table 2: Proximate and HCN composition of fermented and gelatinized peeled and unpeeled cassava tuber meals.

\begin{tabular}{lrrrr}
\hline Parameters (\%) & RPCT* & PFGC & RUCT $^{* *}$ & UFGC \\
\hline Moisture (\%) & 75.22 & 9.84 & 75.81 & 9.72 \\
Crude protein (\% DM) & 2.78 & 2.82 & 3.62 & 3.78 \\
Crude fibre (\% DM) & 3.43 & 3.16 & 4.83 & 4.92 \\
Ash (\% DM) & 3.14 & 3.26 & 4.34 & 4.40 \\
Ether extract (\% DM) & 1.06 & 1.08 & 1.25 & 1.22 \\
Nitrogen free extract (\% DM) & 89.59 & 88.88 & 85.96 & 87.18 \\
HCN (ppm) & 800.00 & 0.00 & 800.00 & 50.00 \\
\hline
\end{tabular}

* Raw peeled cassava tuber meal

** Raw unpeeled cassava tuber meal

meal (UFGC) looked like milled unpolished rice, brownish in colour and also non-dusty. The brownish colour was believed to have been imparted on it by the brown colour of the peels. PFGC appeared like the sun-dried cassava fufu meal produced by Okere (2011), but different from the one produced by Udedibie et al. (2008), which had golden colour, possibly due to the variety of cassava tubers used.

The proximate and HCN composition of the fresh and processed cassava tubers are presented in table 2 . The fresh unprocessed cassava tuber meals (peeled and unpeeled) used in the trial, contained about $800 \mathrm{ppm}$ HCN. After fermentation and gelatinization, the $\mathrm{HCN}$ of the peeled batch dropped to 0ppm, while that of the unpeeled batch dropped to $50 \mathrm{ppm}$. Montaldo (1977) reported that cassava peel have the highest concentration of HCN among cassava parts. This possibly explains the existence of $50 \mathrm{ppm}$ HCN in UFGC. The zero ppm $\mathrm{HCN}$ in PFGC was in agreement with the reports of Udedibie et al. (2008) and Okere (2011) on sun-dried cassava fufu meal.

The crude protein, ether extract and ash contents of UFGC were relatively higher

than those of PFGC. This is understandable because cassava peels contain more of these nutrients than the pulp. Nitrogen-free extract was relatively higher in PFGC. The values were in agreement with the values obtained by Odukwe (1994) in his studies with composite cassava tuber meals. The proximate composition of UFGC was in agreement with the values reported by Udedibie et al. (2008) on sun-dried cassava fufu meal.

\section{Performance of the Starter Broilers}

Data on the performance of the broilers at the starter phase are presented in table 3. The group on UFGC diet recorded significantly $(\mathrm{P}<0.05)$ lower body weight gain, daily body weight gain and higher feed conversion ratio. There were no differences in feed intake among the groups $(\mathrm{P}>0.05)$. The lower weight gain observed in the group on UFGC was similar to reports of Onjoro et al. (1998) that at 100\% replacement of maize with fermented whole cassava meal, broilers tended to gain less weight. The relatively low weight gain observed in UFGC group could be as a result of $\mathrm{HCN}$ content of the diet since UFGC used in the diet contained $50 \mathrm{ppm}$ $\mathrm{HCN}$, implying that the diet contained 
Gelatinization of fermented cassava tuber meal and its nutritive value for broilers

Table 3: Effects of the experimental diets on the performance of the starter broilers.

\begin{tabular}{|c|c|c|c|c|}
\hline \multirow[b]{2}{*}{ Parameters } & \multicolumn{4}{|c|}{ Experimental Diets } \\
\hline & Control & PFGC diet* & UFGC diet** & SEM \\
\hline Av. initial body wt. (g) & 169.48 & 161.77 & 169.75 & 9.78 \\
\hline Av. final body wt. (g) & 1141.25 & 1096.25 & 928.75 & 33.89 \\
\hline Av. body wt. gain (g) & $971.77^{\mathrm{a}}$ & $934.18^{\mathrm{a}}$ & $759.00^{\mathrm{b}}$ & 27.32 \\
\hline Av. daily wt. gain (g) & $34.71^{\mathrm{a}}$ & $33.73^{\mathrm{a}}$ & $27.73^{\mathrm{b}}$ & 0.98 \\
\hline Av. feed intake (g/day) & 81.87 & 83.15 & 82.73 & 1.03 \\
\hline Feed conversion ratio ( $\mathrm{g}$ feed/g gain) & $2.36^{\mathrm{a}}$ & $2.47^{\mathrm{a}}$ & $3.05^{\mathrm{b}}$ & 0.09 \\
\hline Mortality & 0.00 & 0.00 & 0.00 & 0.00 \\
\hline
\end{tabular}

about 25 ppm HCN, which is considered high for young broiler chicks (Udedibie et al., 2004; Chukwuemeka, 2009).

\section{Performance of the finisher broilers}

Data on the performance of the broilers at the finisher phase are presented in table 4 . There were significant differences $(\mathrm{P}<0.05)$ in the performance of the experimental broilers at the finisher phase. The group on UFGC recorded significantly $(\mathrm{P}<0.05)$ higher body weight gain, daily body weight gain and superior feed conversion ratio. This was a complete reversal of the performance in the starter phase. It meant that the birds at the finisher phase were able to overcome the effect of $\mathrm{HCN}$ in the diet and therefore exhibited compensatory growth. Compensatory growth is a phenomenon that enables an animal with retarded growth rate to catch up with final live-weight of the contemporary unretarded ones once the factors responsible for the retarded growth are overcomed (Lawrence and Fowler, 1997). Laying hens and older broilers are known to tolerate dietary $\mathrm{HCN}$ at levels up to $25 \mathrm{ppm}$ (Udedibie and Asoluka, 2008; Enyenihi et al. 2009). Feed intake was not affected by the treatments $(\mathrm{P}>0.05)$.

There were no differences $(\mathrm{P}>0.05)$ in the dressing percentages, the weights of the livers and gizzards of the groups but the weights of the hearts and kidneys were significantly $(\mathrm{P}<0.05)$ reduced by the UFGC diet. The group on PFGC recorded significantly $(\mathrm{P}<0.05)$ more abdominal fat. Similar observations had earlier been made by Udedibie et al. (2008) and Okere (2011).

\section{Conclusion and Recommendation}

The results of the studies have shown that fermentation followed by gelatinization of cassava tubers is a very effective method of processing cassava to eliminate $\mathrm{HCN}$ and solve the problem of dustiness and short shelf-life of cassava products.

Both peeled and unpeeled products could be used to completely replace maize in the diets of broilers but the unpeeled products is preferable in view of the tendency of the peeled product to enhance abdominal fat 
Enyenihi, Esiegwu, Esonu, Uchegbu, and Udedibie

Table 4: Performance of the experimental finisher broilers.

\begin{tabular}{|c|c|c|c|c|}
\hline \multirow[b]{2}{*}{ Parameters } & \multicolumn{4}{|c|}{ Experimental Diets } \\
\hline & Control & PFGC diet* & UFGC diet** & SEM \\
\hline Av. initial body wt. (g) & 1141.25 & 1096.25 & 928.75 & 33.89 \\
\hline Av. final body wt. (g) & 2348.28 & 2378.08 & 2407.25 & 22.03 \\
\hline Av. body wt. gain (g) & $1206.65^{\mathrm{b}}$ & $1281.75^{\mathrm{b}}$ & $1478.25^{\mathrm{a}}$ & 33.09 \\
\hline Av. daily wt. gain (g) & $43.10^{\mathrm{b}}$ & $45.78^{\mathrm{ab}}$ & $52.79^{\mathrm{a}}$ & 1.18 \\
\hline Av. feed intake (g/day) & 160.65 & 158.85 & 154.90 & 2.99 \\
\hline Feed conversion ratio ( $\mathrm{g}$ feed/g gain) & $3.73^{\mathrm{a}}$ & $3.47^{\mathrm{a}}$ & $2.96^{\mathrm{b}}$ & 0.09 \\
\hline \multicolumn{5}{|l|}{ Carcass and Internal Organs ( \% LW) } \\
\hline Dressing percentage & 59.38 & 62.46 & 60.31 & 1.64 \\
\hline Liver & 3.78 & 3.90 & 3.53 & 0.34 \\
\hline Gizzard & 4.04 & 2.80 & 2.47 & 0,86 \\
\hline Heart & $1.14^{\mathrm{a}}$ & $0.93^{\mathrm{a}}$ & $0.69^{b}$ & 0.11 \\
\hline Kidney & $0.71^{\mathrm{a}}$ & $0.59^{\mathrm{a}}$ & $0.44^{\mathrm{b}}$ & 0.065 \\
\hline Abdominal fat & $2.56^{\mathrm{b}}$ & $4.18^{\mathrm{a}}$ & $2.99^{\mathrm{b}}$ & 0.062 \\
\hline
\end{tabular}

accumulation.

The limitations of low crude protein content of the products demands that diets based on them must be supplemented with high protein feeds in view of the disparity in crude protein content between maize and cassava.

\section{References}

Adeyemi, A. 2011. Complete guide to Nigeria tourism, local culture and investment o p p o r t u n t i e s. www.cometonigeria.com

Ayasan, T. 2010. Use of cassava and products in Animal Nutrition. Gaziosmanpasa Universitesi Ziraat Fakultesi Degisi, 27(1): 73-83.
A.O.A.C. 1995. Association of Official Analytical Chemists. Official Methods of Analysis, $17^{\text {th }}$ ed., Washington DC.

Bradbury, J. H. 2004. Wetting method to reduce cyanide content of cassava flour. Cassava Cyanide Diseases Network News, 4: 3 - 4.

Bradbury, M. E., Egan, S. V. and Bradbury, J. H. 1999. Picrate paper kit for determination of total cyanogens in cassava roots and all cyanogens in cassava products. $J$. Sci. Fd. Agric., 79: 595 - 601.

Chauynarog, N., Elangovan, A. V. and Iji, P. A. 2009. The potential of cassava products in diets for poultry. World's Poultry Sci. J., 65:23-35. 
Chukwuemeka, C. M. 2009. Effect of cooking as a method of improving the nutritive value of cassava for starter broilers. B. Agric. Tech. Project Report, Fed. Univ. of Tech., Owerri Nigeria.

Emeh, O. T. 2009. Effects of cooking as a method of improving the nutritive value of cassava for finisher broilers. B. Agric. Tech. Project Reports, Fed. Univ. of Tech., Owerri-Nigeria.

Enyenihi, G. E., Udedibie, A. B. I., Akpan, M. J., Obasi. O. L. and Solomon, I. P. 2009. Effects of 5-hour wetting of sun-dried cassava tuber meal on HCN content and dietary value of the meal for laying hens. Asian J. Anim. and Vet. Adv., 4(6): 326-331.

FAO. 2005. Food and Agricultural Organization of the United Nations Statistics (FAOSTAT database P. ID 567).

Lawrence, T. L. J. and Fowler, V. R. 1997. Growth of Farm Animals. CAB Intl., Wellington UK, Cambridge Press, pp. $1-300$.

Manhungu, N. M., Yamaguchi, Y., Almazau, A. M. and Hahn, S. K. 1987. Reduction of cyanide during processing of cassava to some traditional African foods. J. Fd. Agric., 1: $11-15$.

Montaldo, A. 1977. Whole plant utilization of cassava for animal feed. Proc, Cassava as Animal Feed Workshop, edited by B. Nestle and M. Graham, Ontorio, Canada, IDRC Ottawa, pp. 45 $-46$.

Obioha, F. C., Ngoka, D. A., Alozie, S. and Okpokiri, A. 1984. The value of methionine and palm oil supplementation in cassava-based layer diet. (unpublished data).

Odukwe, C. A. 1994. The Feeding Value of Composite Cassava Root Meal for
Broiler Chickens. Unpublished $\mathrm{PhD}$ Thesis submitted to the Department of Animal Science, Univ. of Nigeria, Nsukka-Nigeria. 182p.

Okere, P. C. 2011. Evaluation of Sun-dried Cassava Fufu Meal as a Source of Dietary Energy for Broilers. Unpuplished M.Sc. Thesis submitted to the Department of Animal Science and Technology, Fed. Univ. of Tech., Owerri-Nigeria. 87p.

Onjoro, P. A., Bhttachrjee, M. and Ottaro, J. M. 1998. Bioconversion of cassava tuber by fermentation into broiler feed of enriched nutritional quality. J. Root Crops, 24: 105 - 110.

Sayre, R. 2007. Transgenic strategies for reducing cyanogens levels in cassava foods. Cassava Cyanide Diseases Network News, 7: 1 - 2.

Snedecor, G. W. and Cochran, W. G. 1978. Statistical Methods, $6^{\text {th }}$ ed., Iowa State Univ. Press, Ames - Iowa.

SPSS. 2004. Statistical package for Social Sciences. Procedure and facilities for Release. McGraw-Hill Book Co., NY.

Udedibie, A. B. I. 2003. In Search of Food: FUTO and the Nutritional Challenge of Canavalia Seeds. $6^{\text {th }}$ Inaugural Lecture, Fed. Univ. of Tech., Owerri Nigeria.

Udedibie, A. B. I., Anyaegbu, B. C., Onyechekwe, G. C. and Ogbukporo, O.C. 2004. Effects of feeding different levels of fermented and unfermented cassava tuber meals on performance of broilers. Nig. J. Anim. Prod., 31: 211 219.

Udedibie, A. B. I. and Asoluka, C. O. 2008. Effects of 5-hour wetting of sundried cassava tuber meal on the $\mathrm{HCN}$ content and dietary value of the meal for young broiler chicks. Nig. J. Anim. Prod., 35: 25 - 31 .

Udedibie, A. B. I., Enyenihi, G. E., 
Akpan, M. J., Obasi, O. L. and Solomon, I. P. 2008. Physiochemical nature and nutritive value of dried

Accepted: 07/08/13 cassava fufu meal for laying hens. Nig. Agric. J., 39: 44 - 49. 